\section{Developmental Response of St. Augustinegrass Cultivars and Experimental Lines in Moderate and Heavy Shade}

\author{
Ben Wherley ${ }^{1}$ \\ Department of Soil and Crop Science, Texas A\&M University, 2474 TAMU, \\ 370 Olsen Boulevard, College Station, TX 77843
}

Ambika Chandra and Anthony Genovesi

Texas A\&M AgriLIFE Research, Dallas, TX 75252

\begin{abstract}
Mason Kearns, Tim Pepper, and Jim Thomas
Department of Soil and Crop Science, Texas A\&M University, 2474 TAMU, 370 Olsen Boulevard, College Station, TX 77843

Additional index words. low light tolerance, photosynthetic photon flux, Stenotaphrum secundatum (Walt) Kuntze, 'Amerishade', 'Captiva', 'Palmetto', 'Raleigh', 'DelMar'
\end{abstract}

\begin{abstract}
St. augustinegrass [Stenotaphrum secundatum (Walt.) Kuntze] is considered to be one of the most shade-tolerant warm-season turfgrasses, yet information is lacking on intraspecies developmental responses and performance in shade. This greenhouse study was conducted to 1) compare quality, development, and physiological responses of 10 commercial and experimental lines of st. augustinegrass in moderate and heavy [32\% and $15 \%$ photosynthetic photon flux $(P P F)$, respectively] shade environments' and 2) evaluate physiological and morphological indicators that could be used in rapid screening for shade tolerance among st. augustinegrass progeny from a segregating population. A range of shade tolerance was observed between the entries, as noted by quality and percent green cover after 10 weeks of imposed shade conditions. In moderate shade, most entries maintained acceptable (6 or greater) quality and greater than $50 \%$ green cover. However, in heavy shade, only 'Captiva', 'Amerishade', and 'PI 600734' maintained acceptable quality, with only PI 600734 and Captiva maintaining greater than 50\% cover. 'TAES 5732-6', an embryo rescue-derived hybrid from 'Floratam', exhibited the least shade tolerance of the group in both shade environments. Neither chlorophyll content nor total nonstructural carbohydrates related well to observed shade quality differences between the entries. A strong correlation existed between shoot elongation rate of a cultivar and its corresponding final percent green cover in moderate shade $\left(R^{2}=0.66\right)$ but not in heavy shade $\left(R^{2}=0.19\right)$, suggesting that moderate shade may be the better environment for discriminating genetic differences among st. augustinegrass germplasm for shade tolerance.
\end{abstract}

Shade is a major challenge for turfgrass managers worldwide. The shade environment can be particularly challenging to warmseason turfgrasses, which have inherently higher light compensation points relative to cool-season grasses (Beard, 1973). Turfgrass physiological responses to shade include reduced pigment levels, nonstructural carbohydrates, increased levels of gibberellic acid, and decreased evapotranspiration, whereas morphological/developmental responses to shade include reduced tillering, thinner and narrower leaves, greater leaf extension rates, and reduced root mass (Dudeck and Peacock, 1992).

St. augustinegrass [Stenotaphrum secundatum (Walt.) Kuntze] is considered one of

Received for publication 2 Apr. 2013. Accepted for publication 14 June 2013.

${ }^{1}$ To whom reprint requests should be addressed; e-mail b-wherley@tamu.edu. the most shade-tolerant warm-season turfgrass species (Beard, 1973; Stier and Gardner, 2008); however, there is limited published information pertaining to comparative shade tolerance of st. augustinegrass. Trenholm and Nagata (2005) compared performance of five st. augustinegrass cultivars in mild to moderate shade ranging from $30 \%$ to $70 \%$ of full sunlight. Cultivars included 'Floratam', 'Seville', 'Palmetto', 'Bitterblue', and '1997-6'. With the exception of 'Floratam', all cultivars maintained acceptable quality and density up to and, in some cases, beyond $60 \%$ shade levels.

In recent years, newer cultivars with reportedly improved shade tolerance such as 'Amerishade' and 'Captiva' have been developed (Brosnan and Deputy, 2008; Trenholm and Kenworthy, 2009); however, published data on their comparative shade tolerance in relation to other commercially available cultivars are lacking. Because it is not uncommon for builders or homeowners to attempt to establish turfgrasses in densely shaded environments receiving $80 \%$ or greater reduction in $P P F$, determining the physiological limits of available cultivars by evaluating them in both moderate and heavily shaded environments would be valuable information.

In addition, for purposes of screening large collections of germplasm or segregating breeding populations for shade tolerance, breeders are continually in search of bioassays that could be used as a tool for more rapid selection of the most shade-tolerant lines. When compared with their less shadetolerant counterparts, strategies used by shadetolerant cultivars or species that enable greater tolerance to shade include greater photosynthetic rates (Miller et al., 2005; Wilkinson et al., 1975), reduced gibberellic acid production (Tan and Qian, 2003), improved carbohydrate allocation to roots (Wherley et al., 2005), and/or less upright leaf orientation (Wherley et al., 2011; Wilkinson and Beard, 1974).

The degree of shade intensity used to screen germplasm for shade tolerance can have a strong impact on the results of a screening. The light compensation point of most turfgrasses is $\approx 2 \%$ to $5 \%$ full sunlight (Beard, 1973). Therefore, it seems plausible that light intensity should be sufficient even in heavy shade (less than $20 \% P P F$ ) to enable screening for shade tolerance differences among various germplasm. Winstead and Ward (1974) used 70\% shade for determining selection indicators when comparing shadeintolerant bermudagrass vs. shade-tolerant st. augustinegrass but found no suitable bioassay that was useful for shade tolerance screening. The light quality (red:far-red) altering effects of vegetative shade are not easily reproduced in controlled environment or greenhouse studies, but reductions in light intensity $(P P F)$ alone can cause many of the photomorphogenic responses observed in shade (Wherley et al., 2005).

The objectives of this study were to 1) compare performance and developmental responses among five commercial cultivars, one Plant Introduction (PI), and four experimental lines of st. augustinegrass to moderate and heavy shade; and 2) determine the appropriate shade intensity level and identify useful indicators for rapid shade screening of a diverse st. augustinegrass germplasm population.

\section{Materials and Methods}

Two 10-week experiments were conducted at Texas A\&M AgriLife Research during 2011 and 2012. Study 1 was conducted from 11 July to 19 Sept. 2011 at Texas A\&M AgriLife, Dallas, TX, whereas Study 2 was conducted from 25 May to 3 Aug. 2012 at Texas A\&M University, College Station, TX. Greenhouse temperatures for both experiments were controlled at $29 / 2{ }^{\circ} \mathrm{C}$ (day/night). Experimental and commercial turfgrass materials used in the study were obtained from the Texas A\&M AgriLife-Dallas breeding program. 
The study included five commercial cultivars, one PI, and four Texas A\&M AgriLIFE advanced experimental lines of st. augustinegrass (Table 1). Before each study, $10 \mathrm{~cm}$ diameter $\times 3-\mathrm{cm}$ deep, round cupcutter plugs of each entry were obtained from established trays, rinsed to remove soil, and planted into the center of a $25 \mathrm{~cm}$ diameter $\times$ $15-\mathrm{cm}$ deep round pot filled with potting soil (Metro-Mix; Sun Gro Horticulture, Agawam, MA). Plugs were then fertilized at a rate of $25 \mathrm{~kg}$ nitrogen $(\mathrm{N}) / \mathrm{ha}$, watered daily, and trimmed weekly at a height of $6.4 \mathrm{~cm}$ until all grasses attained ideal canopy density, color, and quality. This length of pre-treatment growin period required to achieve ideal canopy density for the 2011 study was 6 weeks, whereas only 2 weeks was required for the 2012 study.

Two shade treatment structures were constructed atop adjacent greenhouse benches in the greenhouse using black, density neutral shade fabric (International Greenhouse Company, Danville, IL) constructed to fit custombuilt polyvinylchloride frames $(1 \mathrm{~m}$ tall $\times$ $1.5 \mathrm{~m}$ wide $\times 4 \mathrm{~m}$ long). For producing moderate shade, a $60 \%$ shadecloth was used, which when combined with reductions to full sun $P P F$ caused by greenhouse glass, produced a final shade environment of $32 \% \pm$ $2.4 \% P P F$ relative to full sun. Heavy shade was produced using $80 \%$ shadecloth, which resulted in a final $P P F$ of $15 \% \pm 3.2 \% P P F$ inside shade structures. With the exception of a $25-\mathrm{cm}$ opening around the bottom edge (for allowing air movement), and a $0.6-\mathrm{m}$ opening along the bottom half of the northfacing side of the structure for accessing plants, shadecloth entirely covered the top and all sides of the structures, and pots remained in shade throughout the day. $P P F$ in both structures was confirmed during both studies by obtaining 12 readings using a quantum light meter (Apogee Instruments, Logan, UT) from both inside shade structures and outdoors at solar noon on clear days.

Underneath each shade structure, pots of grasses were arranged in a completely randomized design with three replicate pots per entry. All potted plants were arranged under the shaded area with a $30-\mathrm{cm}$ buffer around the perimeter so as to reduce potential border effects during the study. Pots were also rerandomized after each time point (Weeks 2, 4,6 , and 8) when clippings were collected to further reduce potential for border effects.

To initiate the 10 -week experiments, potted grass plugs were trimmed vertically to a height of $6.4 \mathrm{~cm}$ as well as laterally back to the original $10-\mathrm{cm}$ diameter round plug size. Pots were fertilized at a rate of $24.5 \mathrm{~kg} \mathrm{~N} / \mathrm{ha}$ using a complete fertilizer containing sulfurcoated urea (21-7-14; BCF Products, Greenville, TX) and treated with chlorothalonil fungicide (Syngenta AG, Greensboro, NC) (2,4,5,6-tetrachloro-1,3-benzenedicarbonitrile) at a formulation rate of $1 \mathrm{~g} \cdot \mathrm{m}^{-2}$ at the onset of both studies for prevention of foliar disease. During Study 1, no disease was observed during the remainder of the study on any of the entries. However, during Study 2, fungicide was re-applied to all plants during Week 4 in response to a mild onset of downey mildew (Sclerophthora macrospora) occurring on some cultivars. No further disease was noted during Study 2. Over the course of the experiment, pots were fully watered to field capacity three times weekly.

Leaf elongation rate was evaluated every $14 \mathrm{~d}$ (Weeks 2, 4, 6, 8, and 10) using a ruler to measure the average distance from the soil surface to the tip of the two longest leaves in each pot. The height of cut was subtracted from this length before determining daily leaf elongation rate $\left(\mathrm{mm} \cdot \mathrm{d}^{-1}\right)$. If leaves had lodged over as a result of excessive elongation, they were bunched and held up by hand for measurement. After measurement, pots were trimmed back to their original $6.4 \mathrm{~cm}$ height with clippings discarded. At the conclusion of the experiment, an overall average leaf elongation rate for each replicate was calculated for the five measurement dates.

Table 1. Origin of st. augustinegrass experimental lines and commercial cultivars included in the shade study.

\begin{tabular}{|c|c|c|}
\hline Entry & Original developer & Background \\
\hline \multicolumn{3}{|c|}{ Experimental lines } \\
\hline PI 600734 & $\begin{array}{l}\text { Texas A\&M AgriLife } \\
\text { Research }\end{array}$ & $\begin{array}{l}\text { Plant Introduction from original Texas A\&M germplasm } \\
\text { collection identified for persistence and quality in } \\
\text { reduced light conditions }\end{array}$ \\
\hline DALSA0406 & $\begin{array}{l}\text { Texas A\&M AgriLife } \\
\text { Research }\end{array}$ & $\begin{array}{l}\text { Ecotype selected for field cold tolerance attributes; } \\
\text { advanced line for commercial release }\end{array}$ \\
\hline DALSA0605 & $\begin{array}{l}\text { Texas A\&M AgriLife } \\
\text { Research }\end{array}$ & $\begin{array}{l}\text { Embryo rescue-derived first-generation hybrid with good } \\
\text { gray leaf spot resistance; advanced line for } \\
\text { commercial release }\end{array}$ \\
\hline TAES 5395-4 & $\begin{array}{l}\text { Texas A\&M AgriLife } \\
\text { Research }\end{array}$ & $\begin{array}{l}\text { Embryo rescue-derived first-generation hybrid from } \\
\text { Floratam with good drought resistance characteristics }\end{array}$ \\
\hline TAES 5732-6 & $\begin{array}{l}\text { Texas A\&M AgriLife } \\
\text { Research }\end{array}$ & $\begin{array}{l}\text { Embryo rescue-derived second-generation hybrid from } \\
\text { Floratam; has shown good drought resistance } \\
\text { characteristics }\end{array}$ \\
\hline \multicolumn{3}{|r|}{ Commercial cultivars } \\
\hline Amerishade & The Scotts Company & $\begin{array}{l}\text { Semi-dwarf with reportedly good shade tolerance but } \\
\text { reported susceptibility to disease }\end{array}$ \\
\hline Captiva & University of Florida & $\begin{array}{l}\text { Dwarf type developed as NUF-76 with improved } \\
\text { tolerance to Southern Chinch Bug }\end{array}$ \\
\hline DelMar & The Scotts Company & $\begin{array}{l}\text { Derived from controlled pollination between Seville and } \\
\text { cold tolerant selection }\end{array}$ \\
\hline Palmetto & Sod Solutions & $\begin{array}{l}\text { Selected on a sod farm in Florida; reportedly good cold } \\
\text { tolerance }\end{array}$ \\
\hline Raleigh & $\begin{array}{l}\text { North Carolina Experiment } \\
\text { Station }\end{array}$ & $\begin{array}{l}\text { Possesses excellent cold tolerance and st. augustinegrass } \\
\text { decline resistance }\end{array}$ \\
\hline
\end{tabular}

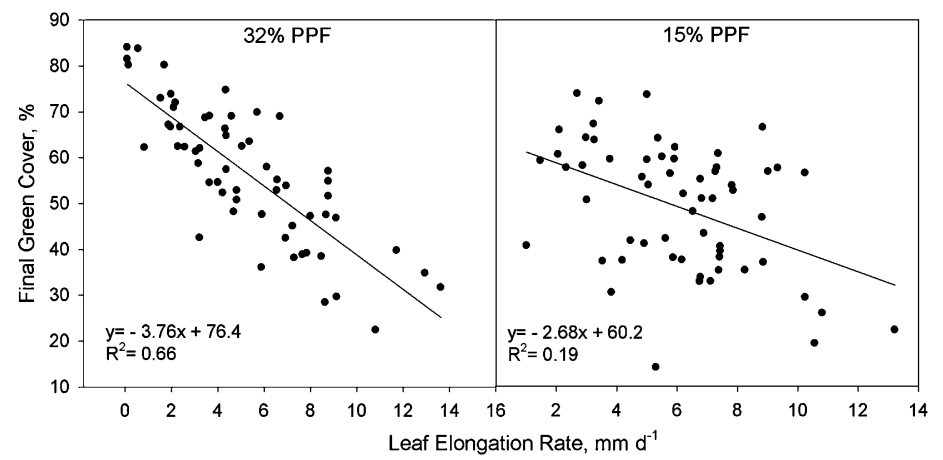

Fig. 1. Scatterplot of leaf elongation rate against final percent green cover in moderate $[32 \%$ photosynthetic photon flux $(P P F)]$ and heavy $(15 \% P P F)$ shade. Data points represent all entries and replicates from both studies.
Visual turf quality was evaluated at the conclusion of the 10-week experimental period using a 1 to 9 scale, where $1=$ dead brown turf, $9=$ perfect green turf, and $6=$ minimally acceptable quality. Digital image analysis was also used to quantify percent green cover of the $81-\mathrm{cm}^{2}$ area of the original potted plug (SigmaScan Pro Version 5.0; SPSS, Chicago, IL) (Richardson et al., 2001). Scatterplots were created by plotting final percent green cover against leaf elongation rates for all entries for both moderate and heavy shade with linear regression performed using Sigma Plot (Systat Software, Inc., San Jose, CA) (Fig. 1).

For Study 2, the chlorophyll content of the newest fully expanded leaf blades of five tillers of each replicate was determined by the method of Moran and Porath (1980) at the end of the study. Briefly, a 3-mm diameter disk was removed from the center of each leaf and placed in $5 \mathrm{~mL}$ of N,N-dimethylformamide in the dark at $4{ }^{\circ} \mathrm{C}$ for $72 \mathrm{~h}$. The absorbance at 664 and $647 \mathrm{~nm}$ was then measured using 
a spectrophotometer (Genesis 10 Series; Thermo Electron Scientific Instruments Corp., Madison, WI). Chlorophyll content $\left(\mu \mathrm{g} \cdot \mathrm{cm}^{-2}\right)$ was then determined by the Moran (1982) formula.

Total nonstructural carbohydrates were extracted from the final set of clipped leaf samples in Study 2 using the boiling water technique (White and Schmidt, 1989). The hot water extract was then tested for carbohydrate concentration using the anthrone reagent procedure (Morris, 1948). Briefly, leaf tissues were harvested during midafternoon and dried at $100{ }^{\circ} \mathrm{C}$ for $1 \mathrm{~h}$ followed by 24 to $28 \mathrm{~h}$ at 60 to $70{ }^{\circ} \mathrm{C}$. After drying, the tissue was ground in a Tecator Cyclotec 1093cyclone sample mill (Foss, Eden Prairie, MN) to pass a $1-\mathrm{mm}$ screen. A total of 0.02 to $0.06 \mathrm{~g}$ of dried tissue was weighed and placed in a centrifuge tube. Ten milliliters of boiling distilled water was added to the tube containing the dried tissue. The solution was mixed using a vortex mixer, covered, and allowed to cool at room temperature for $1 \mathrm{~h}$. The sample was then re-mixed and centrifuged for $10 \mathrm{~min}$ at $2500 \mathrm{rpm}$. A $5-\mathrm{mL}$ aliquot of the supernatant was placed in a $20-\mathrm{mm}$ diameter glass test tube. Ten milliliter of freshly prepared anthrone solution $(0.1 \mathrm{~g}$ anthrone per $50 \mathrm{~mL}$ of $95 \%$ sulfuric acid solution) was added to the test tube, mixed using a vortex mixer, and allowed to stand for $10 \mathrm{~min}$ for color development. The sample was re-mixed and a 3-mL aliquot was transferred to a cuvette. Absorbance at $620 \mathrm{~nm}$ was measured using a spectrophotometer (Genesis 10 Series; Thermo Electron Scientific Instruments Corp., Madison, WI) and compared with a standard curve based on five sucrose concentration solutions ranging from 0.1 to $0.6 \mathrm{~mm} \cdot \mathrm{mL}^{-1}$. A minimum of one standard solution was run with each day's analysis to be sure that the calibration was stable.

Additional root mass development from the initial grass plug sample was also determined at the end of each study. After removing the original $81 \mathrm{~cm}^{2}$ diameter $\times$ $3-\mathrm{cm}$ deep plug from pots, remaining roots/ soil were washed and sieved to remove any attached soil, oven-dried for $72 \mathrm{~h}$ at $65{ }^{\circ} \mathrm{C}$, then weighed to determine root dry weights after each study.

Data for each parameter were subjected to analysis of variance using the general linear model, univariate test procedure using SPSS Version 21.0 (IBM Corp, Armonk, NY) to determine statistical significance of the results. Analysis of variance indicated a significant year effect only for rooting; therefore, other parameters were pooled between studies. Means separation procedures were performed using Fisher's least significant difference test at the $P \leq 0.05$ level.

\section{Results and Discussion}

Turf shade quality. With the exception of 'Palmetto', four of the five cultivars as well as PI 600734 and TAES 5395-4 maintained acceptable quality levels (greater than 6) in moderate shade $(32 \% P P F)$ (Table 2$)$. The top performing entry in terms of final quality in moderate shade was PI 600734, which had a quality rating of 7.2 at the conclusion of the 10-week study. To our knowledge, PI 600734 has not been previously identified for shade tolerance traits but was selected for this trial as a result of its decumbent growth habit and quality over multiple years of infrequent mowing under a polyhouse shelter. Turf quality of the commercial cultivars ranged from 5.6 to 6.3 , but no significant quality differences existed between cultivars in moderate shade. In heavy shade $(15 \% P P F)$, only 'Captiva', 'Amerishade', and PI 600734 maintained acceptable quality levels; however, these were not significantly different from quality ratings of 'DelMarch' or 'Palmetto' (Table 3). 'Raleigh' exhibited the lowest quality (4.7) of the commercial cultivars in heavy shade.

Final green cover. Scores for final green cover showed a similar range of responses as those observed for quality with grasses maintaining between $\approx 30 \%$ and $76 \%$ in moderate

Table 2. St. augustinegrass parameters measured under moderate [32\% photosynthetic photon flux $(P P F)]$ shade. $^{\mathrm{z}}$

\begin{tabular}{|c|c|c|c|c|c|c|c|}
\hline \multicolumn{8}{|c|}{ Moderate shade $(32 \% P P F)$} \\
\hline & \multirow{2}{*}{$\begin{array}{c}\text { Final } \\
\text { turf } \\
\text { quality }\end{array}$} & \multirow{2}{*}{$\begin{array}{l}\text { Final } \\
\text { green } \\
\text { cover }\end{array}$} & \multirow{2}{*}{$\begin{array}{l}\text { Leaf elongation } \\
\text { rate }\end{array}$} & \multicolumn{2}{|c|}{ Root dry wt } & \multirow{2}{*}{$\begin{array}{c}\text { Total nonstructural } \\
\text { carbohydrates }\end{array}$} & \multirow{2}{*}{$\begin{array}{l}\text { Chlorophyll } \\
\text { content }\end{array}$} \\
\hline & & & & Yr 1 & Yr 2 & & \\
\hline Entry & & $(\%)$ & $\left(\mathrm{mm} \cdot \mathrm{d}^{-1}\right)$ & \multicolumn{2}{|c|}{$(\mathrm{g})$} & $\left(\mathrm{mg} \cdot \mathrm{g}^{-1}\right)$ & $\left(\mu \mathrm{g} \cdot \mathrm{cm}^{-2}\right)$ \\
\hline PI 600734 & 7.2 & 75.9 & 0.9 & 12.74 & 0.93 & 15.9 & 17.3 \\
\hline DALSA0406 & 4.7 & 48.1 & 6.6 & 4.77 & 2.31 & 16.2 & 23.1 \\
\hline DALSA0605 & 4.8 & 49.9 & 5.5 & 12.41 & 1.32 & 15.0 & 25.3 \\
\hline TAES 5395-4 & 6.3 & 53.8 & 7.4 & 6.54 & 1.19 & 23.0 & 23.6 \\
\hline TAES 5732-6 & 4.8 & 31.1 & 11.2 & 12.20 & 1.35 & 14.2 & 18.6 \\
\hline Amerishade & 6.0 & 71.4 & 1.5 & 5.11 & 1.06 & 23.6 & 23.2 \\
\hline Captiva & 6.3 & 61.0 & 3.6 & 14.24 & 1.30 & 16.0 & 20.2 \\
\hline DelMar & 6.2 & 60.9 & 5.2 & 5.96 & 2.31 & 14.2 & 17.3 \\
\hline Palmetto & 5.6 & 52.6 & 5.6 & 7.45 & 1.62 & 11.2 & 17.8 \\
\hline Raleigh & 6.3 & 61.1 & 5.1 & 9.98 & 0.98 & 13.2 & 25.0 \\
\hline $\operatorname{LSD}(0.05)$ & 1.3 & 9.1 & 1.3 & NS & NS & NS & NS \\
\hline \multicolumn{8}{|l|}{ ANOVA } \\
\hline Year & NS & NS & NS & $*$ & $*$ & - & - \\
\hline Entry & $*$ & $* * *$ & $* * *$ & NS & NS & NS & NS \\
\hline Year $\times$ entry & NS & NS & NS & NS & NS & 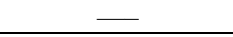 & - \\
\hline
\end{tabular}

${ }^{z}$ Except for total nonstructural carbohydrates and chlorophyll, which were measured only for Study 2 , means have been pooled across experiments.

NS, ***,**,* Nonsignificant or significant at $P \leq 0.001,0.01$, or 0.05 , respectively.

$\mathrm{LSD}=$ least significant difference; ANOVA $=$ analysis of variance.

Table 3. St. augustinegrass parameters measured under heavy [15\% photosynthetic photon flux $(P P F)]$ shade. $^{\mathrm{z}}$

\begin{tabular}{|c|c|c|c|c|c|c|}
\hline \multicolumn{7}{|c|}{ Heavy shade $(15 \% P P F)$} \\
\hline & $\begin{array}{l}\text { Final turf } \\
\text { quality }\end{array}$ & $\begin{array}{c}\text { Final green } \\
\text { cover }\end{array}$ & $\begin{array}{l}\text { Leaf elongation } \\
\text { rate }\end{array}$ & $\begin{array}{l}\text { Root } \\
\text { dry wt }\end{array}$ & $\begin{array}{c}\text { Total nonstructural } \\
\text { carbohydrates }\end{array}$ & $\begin{array}{c}\text { Chlorophyll } \\
\text { content }\end{array}$ \\
\hline Entry & & $(\%)$ & $\left(\mathrm{mm} \cdot \mathrm{d}^{-1}\right)$ & (g) & $\left(\mathrm{mg} \cdot \mathrm{g}^{-1}\right)$ & $\left(\mu \mathrm{g} \cdot \mathrm{cm}^{-2}\right)$ \\
\hline PI 600734 & 6.1 & 59.0 & 2.6 & 1.63 & 17.0 & 24.7 \\
\hline DALSA0406 & 4.4 & 44.7 & 7.2 & 4.29 & 27.4 & 29.4 \\
\hline DALSA0605 & 4.3 & 37.5 & 6.6 & 6.51 & 17.2 & 22.6 \\
\hline TAES 5395-4 & 5.2 & 41.0 & 7.5 & 2.26 & 18.0 & 22.4 \\
\hline TAES 5732-6 & 4.1 & 24.6 & 10.5 & 4.57 & 16.4 & 22.9 \\
\hline Amerishade & 6.1 & 46.9 & 2.8 & 2.86 & 14.6 & 27.3 \\
\hline Captiva & 6.3 & 51.3 & 4.9 & 3.24 & 17.7 & 30.7 \\
\hline DelMar & 5.5 & 48.5 & 4.9 & 5.40 & 16.9 & 18.0 \\
\hline Palmetto & 5.4 & 49.1 & 7.0 & 6.53 & 15.2 & 23.6 \\
\hline Raleigh & 4.7 & 37.8 & 6.7 & 5.67 & 14.3 & 22.8 \\
\hline LSD $(0.05)$ & 1.0 & 15.8 & 1.4 & NS & NS & NS \\
\hline \multicolumn{7}{|l|}{ ANOVA } \\
\hline Year & NS & NS & NS & NS & - & - \\
\hline Entry & $*$ & $* *$ & $* * *$ & NS & NS & NS \\
\hline Year $\times$ entry & NS & NS & NS & NS & - & 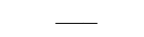 \\
\hline
\end{tabular}

${ }^{\mathrm{z}}$ Except for total nonstructural carbohydrates and chlorophyll, which were measured only for Study 2 means have been pooled across experiments.

$\mathrm{NS}, * * *, * *, *$ Nonsignificant or significant at $P \leq 0.001,0.01$, or 0.05 , respectively.

$\mathrm{LSD}=$ least significant difference; ANOVA $=$ analysis of variance. 
shade. In this environment, all commercial entries as well as two of the five experimentals maintained greater than $50 \%$ cover (Table 2). 'Amerishade' and PI 600734 maintained the highest levels of green cover in moderate shade $(75.9 \%$ and $71.4 \%$, respectively), both of which significantly outperformed the four best commercial cultivars in their respective groups. The least shadetolerant entry in the study in terms of quality and cover in both shade treatments was TAES 5732-6. This may not be surprising given that this experimental line is a firstgeneration embryo rescue-derived hybrid from 'Floratam' (Genovesi et al., 2009), which has been shown to possess relatively poor shade tolerance in past studies (Barrios et al., 1986; Trenholm and Nagata, 2005). In heavy shade, only 'Captiva' and PI 600734 maintained greater than $50 \%$ green cover, whereas cover was reduced to as low as $24.6 \%$ for TAES 5732-6 (Table 3).

Shade tolerance indicators. Leaf elongation rates, root dry weights, total nonstructural carbohydrates, and chlorophyll contents were all examined as potential indicators for shade tolerance in both moderate and heavy shade (Tables 2 and 3). In moderate shade, leaf elongation rates significantly differed between entries, ranging from as low as $0.9 \mathrm{~mm} \cdot \mathrm{d}^{-1}$ for PI 600734 to as high as $11.2 \mathrm{~mm} \cdot \mathrm{d}^{-1}$ for TAES 5732-6. Among the commercial cultivars, 'Amerishade' $\left(1.5 \mathrm{~mm} \cdot \mathrm{d}^{-1}\right)$ and 'Captiva' $\left(3.6 \mathrm{~mm} \cdot \mathrm{d}^{-1}\right)$ had significantly lower elongation rates than cultivars DelMar, Palmetto, and Raleigh. In heavy shade, elongation rates ranged from $2.6 \mathrm{~mm} \cdot \mathrm{d}^{-1}$ (PI 600734) to $10.5 \mathrm{~mm} \cdot \mathrm{d}^{-1}$ (TAES 5732-6). Significant differences for elongation rates were observed between the cultivars tested in heavy shade, ranging from a low of $2.8 \mathrm{~mm} \cdot \mathrm{d}^{-1}$ ('Amerishade') to a high of $7 \mathrm{~mm} \cdot \mathrm{d}^{-1}$ ('Palmetto'). These results are consistent with past characterization of 'Amerishade' and 'Captiva' as "dwarf" or "semi-dwarf" types based on their diminutive growth habits (Brosnan and Deputy, 2008; Trenholm and Kenworthy, 2009).

Although in practice, st. augustinegrass would generally be mowed with greater frequency, this study was designed to maximize differences in shade avoidance responses among the entries. A 14-d clipping interval was also used by Trenholm and Nagata (2005) in screening st. augustinegrass cultivars for shade tolerance. It is plausible that a greater clipping frequency could have potentially resulted in somewhat improved quality of plants in this study, because greater frequency of mowing can promote increased tillering and/or more favorable carbohydrate allocation in plants (Beard, 1973; Bell, 2011).

Scatterplots of leaf elongation rate vs. final percent cover for all entries in moderate shade revealed that a strong correlation $\left(R^{2}=\right.$ 0.66 ) between these two parameters (Fig. 1). However, this response was much less pronounced in heavy shade $\left(R^{2}=0.19\right)$. This correlation indicates that elongation rate in moderate shade may be an effective indicator of st. augustinegrass shade tolerance. Furthermore, heavy shade $(15 \% P P F)$ may be too extreme for detecting meaningful differences between st. augustinegrass genotypes in response to shade.

Among the other parameters evaluated as potential shade tolerance indicators (root dry weights, total nonstructural carbohydrates, and chlorophyll content), considerable variability existed. More importantly, there were no significant detectable differences or trends that would suggest an apparent relationship with shade tolerance level for use as a screening indicator in st. augustinegrass (Tables 2 and 3 ). In fact, the least shade-tolerant entry (5732-6), which has also been identified as possessing good drought resistance (Chandra, unpublished data), showed similarly greater root development in shade than many of the other entries (Tables 2 and 3). A significant year effect was observed for root dry weights in moderate shade with significantly greater root development occurring after Study 1, but this was attributable to the extra 4 weeks ( 6 vs. 2 weeks) of establishment that were provided before initiating Study 1 (Table 2).

It has been suggested that grass plants do not appear to store excess carbohydrates during the growing season beyond a predetermined level using whatever excess carbohydrates are available to form new tillers and daughter plants (Bell, 2011), which may explain the lack of differences observed between entries for nonstructural carbohydrates. Similar results were reported for tall fescue, in which chlorophyll contents did not differ between shade-tolerant 'Plantation' and shade-intolerant 'Equinox' when grown in $90 \%$ density neutral or deciduous shade environments (Wherley et al., 2005). In contrast, 'Celebration' bermudagrass was reported to have superior quality relative to other tested bermudagrasses grown in shade with the authors noting its enhanced levels of chlorophyll, root length, and root biomass in shade (Baldwin et al., 2008).

Extension of results to field situations. Based on these results, although most st. augustinegrass cultivars performed well under moderate shade, only PI 600734, 'Captiva', and 'Amerishade' maintained acceptable quality and cover in heavy $(85 \%)$ shade. It should be emphasized that these results are based on 10-week greenhouse studies under ideal temperature and moisture conditions with plants that were treated with fungicide. Anecdotal observations and field reports have emerged in recent years to suggest that dwarf/ semidwarf st. augustinegrass types that have shown good shade tolerance in these studies may also be more susceptible to fungal disease in shade (Brosnan and Deputy, 2008), possibly as a result of their lower rates of shoot growth. Incidentally, we did observe a mild case of downey mildew developing primarily on the dwarf-type entries 'Amerishade' and 'Captiva' during Study 2. Genetic differences in tolerance to disease as well as other stresses such as low temperature and insects could also affect long-term adaptation and persistence in shade, although longer-term field evaluations would be needed to fully evaluate these traits. Therefore, when breeding for greater shade tolerance, the importance of other agronomic traits should not be overlooked.

\section{Literature Cited}

Baldwin, C., H. Liu, and L.B. McCarty. 2008. Diversity of 42 bermudagrass cultivars in a reduced light environment. Acta Hort. 783:147157.

Barrios, E.P., F.J. Sundstorm, D. Babcock, and L. Leger. 1986. Quality and yield response of four warm-season lawngrasses to shade conditions. Agron. J. 78:270-273.

Beard, J.B. 1973. Turfgrass science and culture. Prentice Hall, Englewood Cliffs, NJ.

Bell, G.E. 2011. Turfgrass physiology and ecology: Advanced management principles. Cambridge University Press, Cambridge, UK.

Brosnan, J. and J. Deputy. 2008. St. Augustinegrass. University of Hawaii Cooperati Extension Service Bulletin TM-3. 1 Apr. 2013. <http://www. google.com/url? sa =t\&rct=j\&q=brosnan $\%$ 20 deputy $\% 20 \mathrm{st} \% 20$ aug \& source $=$ web \&cd $=$ 1 \&ved=0CDEQFjAA\&url=http $\% 3 \mathrm{~A} \% 2 \mathrm{~F} \%$ 2Fwww.ctahr.hawaii.edu $\% 2$ Foc $\% 2$ Freepubs $\%$ 2Fpdf\%2FTM-3.pdf\&ei=lgyNUYD0J7Hd4 APBo4CYAw\&usg=AFQjCNH dRS8zR7RQ UrrjL0JQH_1gN9DUiQ>.

Dudeck, A.E. and C.H. Peacock. 1992. Shade and turfgrass culture, p. 269-284. In: Waddington, D.V. R.N. Carrow, and R.C. Shearman (eds.). Turfgrass. Amer. Soc. Agron. Monograph No. 32. Madison, WI.

Genovesi, A.D., R.W. Jessup, M.C. Engelke, and B.L. Burson. 2009. Interploid St. Augustinegrass [Stenotaphrum secundatum (Walt.) Kuntze] hybrids recovered by embryo rescue. In Vitro Cell. Dev. Biol. Plant 45:659-666.

Miller, G.L., J.T. Edenfield, and R.T. Nagata. 2005. Growth parameters of Floradwarf and Tifdwarf bermudagrass exposed to various light regimes. Intl. Turfgrass Soc. Res. J. 10:879-884.

Moran, R. 1982. Formulae for determination of chlorophyllous pigments extracted with $\mathrm{N}, \mathrm{N}-$ dimethylformamide. Plant Physiol. 69:13761381.

Moran, R. and D. Porath. 1980. Chlorophyll determination in intact tissues using N,N- dimethylformamide. Plant Physiol. 65:478-479.

Morris, D.L. 1948. Quantitative determination of carbohydrates with Dreywood's anthrone reagent. Science 107:254-255.

Richardson, M.D., D.E. Karcher, and L.C. Purcell. 2001. Quantifying turfgrass cover using digital image analysis. Crop Sci. 41:1884-1888.

Stier, J.C. and D.S. Gardner. 2008. Shade stress and management, p. 447-471. In: Pessarakli, M. (ed.). Turfgrass management and physiology. CRC Press, Boca Raton, FL.

Tan, Z.G. and Y.L. Qian. 2003. Light intensity affects gibberellic acid content in Kentucky bluegrass. HortScience 38:113-116.

Trenholm, L.E. and K. Kenworthy. 2009. 'Captiva' St. Augustinegrass. UF IFAS Extension Bulletin ENH1137. 1 Apr. 2013. <http://www.google.com/ url? $\mathrm{sa}=\mathrm{t} \& \mathrm{rct}=\mathrm{j} \& \mathrm{q}=\&$ esrc $=\mathrm{s} \&$ source $=$ web $\& \mathrm{~cd}=$ $2 \&$ ved $=0$ CD 8 QFjAB\&url=http $\% 3 \mathrm{~A} \% 2 \mathrm{~F} \%$ 2Fedis.ifas.ufl.edu $\% 2 \mathrm{Fpdffiles} \% 2$ FEP $\%$ 2FEP39800.pdf\&ei=dg-NUcqQE4Lk9AT k0YHICA\&usg=AFQjCNGKkOc_LpThf3L WL9WmV0uFEKPVow\&bvm=bv.46340616, d.eWU>.

Trenholm, L.E. and R.T. Nagata. 2005. Shade tolerance of St. Augustinegrass cultivars. HortTechnology 15:267-272. 
Wherley, B.G., D.S. Gardner, and J.D. Metzger. 2005. Tall fescue photomorphogenesis as influenced by changes in the spectral composition and light intensity. Crop Sci. 45:562-568.

Wherley, B.G., P. Skulkaew, A. Chandra, A.D. Genovesi, and M.C. Engelke. 2011. Low-input performance of zoysiagrass (Zoysia spp.) cultivars maintained under dense tree shade. HortScience 46:1033-1037.
White, R.H. and R.E. Schmidt. 1989. Bermudagrass response to chilling temperatures as influenced by iron and benzyladenine. Crop Sci. 29:768-773.

Wilkinson, J.F. and J.B. Beard. 1974. Morphological responses of Poa pratensis and Festuca rubra to reduced light intensity, p. 231-241. In: Roberts, E.C. (ed.). Proc. 2nd Int. Turfgrass Res. Conf. ASA, CSSA, Madison, WI.
Wilkinson, J.F., J.B. Beard, and J.V. Krans. 1975. Photosynthetic-respiratory responses of 'Merion' kentucky bluegrass and 'Pennlawn' red fescue at reduced light intensities. Crop Sci. 15:165-168.

Winstead, C.W. and C.Y. Ward. 1974. Persistence of southern turfgrasses in a shade environment, p. 221-230. In: Roberts, E.C. (ed.). Proc. 2nd Intl. Turfgrass Res. Conf. ASA, CSSA, Madison, WI. 